\title{
Radioactive Investigation of Sand from the Northern Region of Kuwait
}

\author{
Karim N. Jallad ${ }^{1}$ \\ ${ }^{1}$ College of Arts and Sciences, American University of Kuwait, Kuwait \\ Correspondence: Karim N. Jallad, College of Arts and Sciences, American University of Kuwait, P. O. Box 3323, \\ Safat 13034, Kuwait. Tel: 965-2224-8399-423. E-mail: kjallad@auk.edu.kw
}

Received: August 13, $2013 \quad$ Accepted: August 26, $2013 \quad$ Online Published: September 9, 2013
$\begin{aligned} & \text { doi:10.5539/enrr.v3n4p68 } \\ & \text { URL: http://dx.doi.org/10.5539/enrr.v3n4p68 }\end{aligned}$

\begin{abstract}
Geological materials were collected from the northern region of the state of Kuwait for radioactive characterization. The northern region extended for an approximate distance of $100 \mathrm{~km}$ along highway 80 running from the north of Kuwait City to the Kuwaiti-Iraqi border. Back in 1991, during the Gulf War, this highway was called the highway of death due to the occurrence of intense combat and sabotage activities. Gamma-ray spectroscopic measurements were conducted on the geological materials collected to investigate the concentration of both natural and man made radio nuclides. From the gamma measurements, the mean activity concentration for the radio nuclides investigated were as follows; Uranium-238 at $11 \mathrm{~Bq} / \mathrm{kg}$, Thorium-232 at 30 $\mathrm{Bq} / \mathrm{kg}$, Radium-226 at $12 \mathrm{~Bq} / \mathrm{kg}$, Potassium-40 at $397 \mathrm{~Bq} / \mathrm{kg}$, Cesium-137 at $2.0 \mathrm{~Bq} / \mathrm{kg}$, and Iodine-131 at 19.0 $\mathrm{Bq} / \mathrm{kg}$. The conclusion reached in this study illustrated that in general the radioactivity concentration of the radio nuclides investigated are both low and below international levels.
\end{abstract}

Keywords: radio nuclides, Kuwait, Gulf War, depleted uranium, cesium-137

\section{Introduction}

By far the largest proportion of human exposure to radiation comes from external natural sources of radiation, which includes cosmic radiation or from inhalation or ingestion of naturally occurring primordial radioactive materials in surface soil such as uranium, thorium, and potassium. In Kuwait, besides the coastal deposits, the geological topography is relatively uniform with prevailing smooth sand sheets having relatively consistent concentrations of naturally occurring radio nuclides (Saad \& Al-Azmi, 2002).

However, the Gulf War in 1991 has led to heavy contamination of the Kuwaiti territory. During the Gulf War, over 1150 wells out of 1313 operating wells were sabotaged in Kuwait by the Iraqi Army. Not all of the wells caught fire, and many just released crude oil as gushers that contaminated the environment and formed many artificial oil lakes. However, the wells that caught fire burned for more than 250 days at an estimated rate of 3 million barrels per day sending enormous smoke plumes containing gaseous toxic combustion products and radioactive species into the air. After which the fly ashes descended and deposited on the sand (Barnaby, 1991; Abdullah, Saad, Farhan, \& Sharma, 2008).

In addition, the use of depleted uranium (400-800 tons) in the Gulf War played a significant role in the radioactive contamination of the surface soil in Kuwait. Depleted uranium has a half-life of 4.4 billion years and it is a by-product of the production of enriched uranium for use in nuclear reactors and in the manufacture of nuclear weapons. Since depleted uranium has a high density $\left(19.1 \mathrm{~g} / \mathrm{cm}^{3}\right)$, it is used by the military in defensive armor plating and in armor piercing projectiles. When the super-high velocity depleted uranium munitions explode, the kinetic energy generated upon impact is so high that the depleted uranium actually vaporizes and transforms into fine oxidized particulate matter that slowly settles on the sand. Unfortunately, depleted uranium still contains about $30 \%$ of the radioactivity found in enriched uranium, and is extremely dangerous to humans and animals (Barnaby, 1991).

No studies regarding the distribution and the concentrations of radioactive nuclides were conducted in the state of Kuwait prior to the Gulf War; however, after the war, a number of studies were published addressing the radioactive contamination in Kuwait where the latest article was at least ten years old (Al-Azmi, Saad, \& Farhan, 1999; Saad \& Al-Azmi, 2002; Bou-Rabee \& Bem, 1996). In addition, a survey was conducted to assess the 
radiological conditions arising owing to depleted uranium residues in 2003 by the International Atomic Energy Agency (IAEA, 2003) and another in 2005 by the Kuwait Institute for Scientific Research to establish a radiological atlas for the state of Kuwait (KISR, 2008).

In this research article, concentrations of radioactive materials, were measured along highway 80 , called Highway of Death during the Gulf War, running from north of Kuwait city to the Kuwaiti-Iraqi border. This study aims at comparing the current radionuclide concentrations to eight year old published data, correlating the radioactivity concentrations to radiation contamination incidents happened during the Gulf War, and identifying areas which might be radiologically hazardous.

\section{Materials and Methods}

The 16 sites from which the sand samples were collected are shown in Figure 1. These locations were along Highway 80. At each of the collection sites, a sampling area of $1 \mathrm{~m}^{2}$ was considered, where three samples were taken, each weighing $500 \mathrm{~g}$. The sand samples were taken at a depth of $5 \mathrm{~cm}$ from the surface and placed in a plastic bag after which it was air shipped for analysis at Pace Analytical Services, a radioactive analysis lab, located in Greensburg, PA, USA.

All samples were dried in an oven at $105{ }^{\circ} \mathrm{C}$ overnight. Dried samples were pulverized using a mortar and pestle then mixed thoroughly to homogenize. A portion of the dried, pulverized solid sample was split for gamma spectroscopy analysis using a modified EPA 901.1 protocol. Samples were prepared in sealed 8-ounce can geometry for non-destructive gamma spectroscopy analysis on a high-purity Ge detector. The samples were analyzed for the following radio nuclides: U-238, Th-232, Ra-226, K-40, Cs-137 and I-131.

The analysis was performed by individually placing the prepared can samples directly on the end cap of a high purity Ge gamma detector. A spectrum of each sample was acquired for a duration of one hour. The measured energies of the resultant gamma photo peaks for each sample were compared to a comprehensive "library" of known photo peaks. Ra-226 does emit a gamma ray near $186 \mathrm{keV}$; however, this peak conflicts with a known gamma ray for naturally-occurring U-235. In order to prevent the misidentification of Ra-226, each sample was processed as described in the sample pre-treatment section above, with final hermetic sealing of the 8-ounce can. Once prepared, samples were stored for a minimum of 21-days to allow complete in growth of Ra-226 with its daughters $\mathrm{Rn}-222$ (which is a gas), $\mathrm{Pb}-214$, and $\mathrm{Bi}-214$. Both $\mathrm{Pb}-214$ and $\mathrm{Bi}-214$ exhibit strong gamma rays without interferences and so, these peaks were used to quantify the Ra-226 present in each sample by inference. Likewise, the concentration of U-238 was inferred from peak contributions from its daughters Th-234 and $\mathrm{Pa}-234 \mathrm{~m}$. All other reported analytes were measured directly using known photo peaks attributable to the analyte which was reported as shown in Table 1.

Table 1. Gamma rays and their related isotopes used to calculate the activity concentrations of the investigated radio nuclides

\begin{tabular}{cccc}
\hline Nuclide & Half-Life & Gamma ray energy $(\mathrm{keV})$ & Isotope \\
\hline${ }^{232} \mathrm{Th}$ & $1.405 \times 10^{10} \mathrm{yr}$ & 238.6 & ${ }^{212} \mathrm{~Pb}$ \\
& & 727.17 & ${ }^{212} \mathrm{Bi}$ \\
& & 338.14 & ${ }^{228} \mathrm{Ac}$ \\
${ }^{238} \mathrm{U}$ & $4.468 \times 10^{9} \mathrm{yr}$ & 969 & ${ }^{228} \mathrm{Ac}$ \\
& & 63.09 & ${ }^{234} \mathrm{Th}$ \\
${ }^{226} \mathrm{Ra}$ & $1650 \mathrm{yr}$ & 609.3 & ${ }^{234 \mathrm{~m}} \mathrm{~Pa}$ \\
& & 1120.3 & ${ }^{214} \mathrm{Bi}$ \\
& & 295.2 & ${ }^{214} \mathrm{Bi}$ \\
${ }^{40} \mathrm{~K}$ & $1.277 \mathrm{x} 10^{9} \mathrm{yr}$ & 351.9 & ${ }^{214} \mathrm{~Pb}$ \\
${ }^{137} \mathrm{Cs}$ & $30.17 \mathrm{yr}$ & 1460.8 & ${ }^{40} \mathrm{Ar}$ \\
${ }^{131} \mathrm{I}$ & $8.02 \mathrm{~d}$ & 661.66 & ${ }^{137} \mathrm{Ba}$ \\
& & 971 & ${ }^{131} \mathrm{Xe}$ \\
\hline
\end{tabular}


Results for all samples were calculated using energy and efficiency calibrations performed implementing a NIST-traceable calibration source prepared in an equivalent geometry as the processed samples. Corrections were made to each sample spectra for contributions of analytes found present in the ambient background for the specific detector utilized. Decay corrections for each reported analyte were applied back to the sample collection date and time. The primary library used for sample gamma analysis was Pace's comprehensive default library. The MDC (Minimum Detectable Concentration) type used for primary analysis was the Regulatory Guide 4.16 calculation included as an option in the Gamma Vision V. 6.08 software program. This option was chosen as it most closely matches Pace's default MDC calculation used for all other radiochemistry analyses. No anomalous events were noted during the preparation or analysis of the samples for gamma spectroscopy analysis. All data quality objectives and quality control acceptance criteria were satisfied.

\section{Results and Discussion}

A total of 48 sand samples were collected from selected locations shown in Figure 1. The samples geographic locations are determined by a Global Positioning System and are listed in Table 2. The activity concentrations of the U-238, Th-232, Ra-226, K-40, Cs-137 and I-131 in the sand samples analyzed are plotted in Figures 2-7. The radionuclide concentrations are calculated in $\mathrm{Bq} / \mathrm{kg}$ on a dry weight basis. The northern part of Kuwait, specifically Highway 80 running from Kuwait city to the Kuwaiti-Iraqi border, has witnessed intensive military activity during the Gulf War back in 1991 due to the extensive use of depleted uranium munitions by ground and air coalition forces (Barnaby, 1991). In addition to, since the northern Kuwaiti oil fields located in the vicinity of Highway 80 account approximately for $35 \%$ of the total oil produced in Kuwait, a number of oil wells were sabotaged and set on fire (Abdullah, Saad, Farhan \& Sharma, 2008; Saad \& Al-Azmi, 2002). All these actions might have led to radioactive contamination by elevating the levels of radioactive nuclides in the sand. However, it is expected that surface sand has shifted since 1991 due to winds and sandstorms.

Uranium occurs naturally in the environment since it is found in trace amounts in all rocks, soil, water and air. Uranium has three isotopes to include both Uranium-238 and Uranium-235 which are primordial radionuclides, while Uranium-234 is produced by the radioactive decay of Uranium-238. The content of Uranium-238 in natural uranium is around $99.3 \%$, while it is $98.8 \%$ in depleted uranium. As shown in Figure 2, the highest concentration of Uranium-238 was found at the beginning of Highway 80 (6.731-32.338 Bq/kg; Sites 1, 2, 14, 15, and 16), where intense bombing and combat fighting took place during the Gulf War. The second highest was detected in sand samples collected from a deserted bombed village

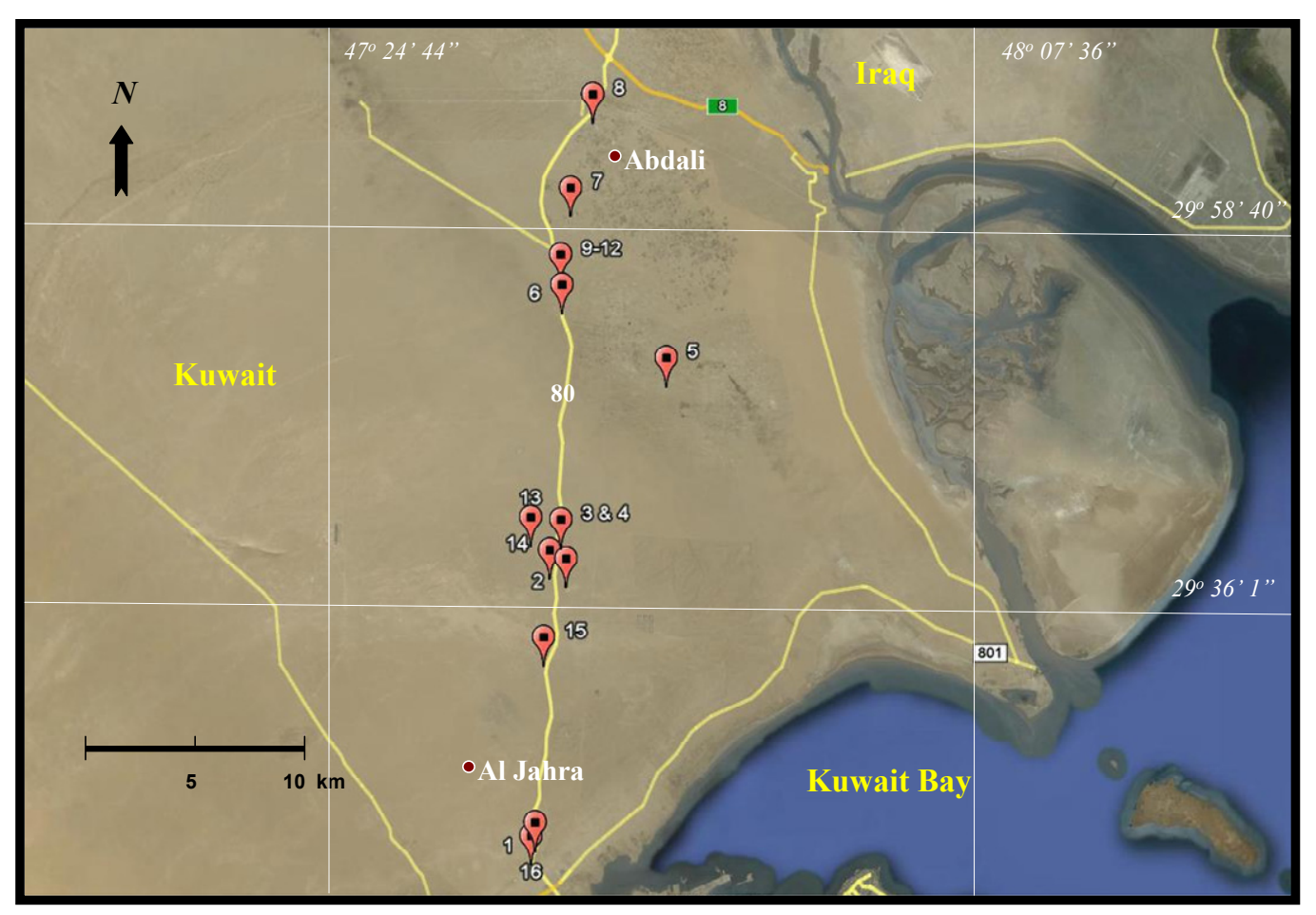

Figure 1. Map of the study area 
Table 2. The locations of the samples sites

\begin{tabular}{|c|c|c|c|c|c|c|c|c|c|}
\hline \multirow[t]{2}{*}{ Site } & \multirow[t]{2}{*}{ Latitude } & \multirow[t]{2}{*}{ Longitude } & \multirow[t]{2}{*}{ Site Description } & \multicolumn{6}{|c|}{ Mean Activity $(\mathrm{Bq} / \mathrm{kg})$} \\
\hline & & & & ${ }^{238} \mathrm{U}$ & ${ }^{232} \mathrm{Th}$ & ${ }^{226} \mathrm{Ra}$ & ${ }^{40} \mathrm{~K}$ & ${ }^{237} \mathrm{Cs}$ & ${ }^{131} \mathrm{I}$ \\
\hline 1 & $29^{\circ} 24^{\prime} 42.3698^{\prime \prime} \mathrm{N}$ & $47^{\circ} 38^{\prime} 27.3834^{\prime \prime} \mathrm{E}$ & open area used for camping & 6.73 & 28.9 & 11.8 & 403 & 1.92 & 14.1 \\
\hline 2 & $29^{\circ} 39^{\prime} 52.7104^{\prime \prime} \mathrm{N}$ & $47^{\circ} 40^{\prime} 37.7851 " \mathrm{E}$ & open area used for camping & 14.6 & 37.0 & 13.0 & 38.1 & 1.85 & 0 \\
\hline 3 & $29^{\circ} 37^{\prime} 21.3736^{\prime \prime} \mathrm{N}$ & $47^{\circ} 45^{\prime} 6.1789^{\prime \prime} \mathrm{E}$ & bombed weather station & 0.04 & 60.3 & 13.4 & 42.6 & 0.96 & 15.7 \\
\hline 4 & $29^{\circ} 37^{\prime} 21.3736^{\prime \prime} \mathrm{N}$ & $47^{\circ} 45^{\prime} 6.1789^{\prime \prime} \mathrm{E}$ & bombed weather station & 0.52 & ND* & 12.3 & 37.7 & 4.44 & 21.5 \\
\hline 5 & $29^{\circ} 46^{\prime} 33.3473^{\prime \prime} \mathrm{N}$ & $47^{\circ} 41^{\prime} 3.7398^{\prime \prime} \mathrm{E}$ & oil field & ND* & 12.5 & 12.3 & 40.3 & 0.63 & $\mathrm{ND}^{*}$ \\
\hline 6 & $29^{\circ} 53^{\prime} 57.6535^{\prime \prime} \mathrm{N}$ & $47^{\circ} 36^{\prime} 43.1826^{\prime \prime} \mathrm{E}$ & median area of highway 80 & ND* & 33.6 & 10.5 & 39.2 & 1.22 & 14.6 \\
\hline 7 & $29^{\circ} 58^{\prime} 56.8361 " \mathrm{~N}$ & $47^{\circ} 40^{\prime} 32.3443^{\prime \prime} \mathrm{E}$ & agricultural farms & 6.77 & 26.7 & 11.5 & 37.7 & 1.30 & 34.7 \\
\hline 8 & $30^{\circ} 4^{\prime} 40.3447 " \mathrm{~N}$ & $47^{\circ} 42^{\prime} 5.0918^{\prime \prime} \mathrm{E}$ & border between Kuwait \& Iraq & 14.5 & 16.5 & 13.4 & 36.6 & 1.52 & $\mathrm{ND}^{*}$ \\
\hline 9 & $29^{\circ} 53^{\prime} 57.6535^{\prime \prime} \mathrm{N}$ & $47^{\circ} 36^{\prime} 43.1826^{\prime \prime} \mathrm{E}$ & bombed town & 17.4 & 17.1 & 14.2 & 38.1 & 2.18 & 15.4 \\
\hline 10 & $29^{\circ} 53^{\prime} 57.6535^{\prime \prime} \mathrm{N}$ & $47^{\circ} 36^{\prime} 43.1826^{\prime \prime} \mathrm{E}$ & bombed town & 11.2 & $\mathrm{ND}^{*}$ & 9.77 & 411 & 2.66 & $\mathrm{ND}^{*}$ \\
\hline 11 & $29^{\circ} 53^{\prime} 57.6535^{\prime \prime} \mathrm{N}$ & $47^{\circ} 36^{\prime} 43.1826^{\prime \prime} \mathrm{E}$ & bombed town & 4.96 & 69.2 & 12.6 & 411 & 2.78 & $\mathrm{ND}^{*}$ \\
\hline 12 & $29^{\circ} 53^{\prime} 57.6535^{\prime \prime} \mathrm{N}$ & $47^{\circ} 36^{\prime} 43.1826^{\prime \prime} \mathrm{E}$ & bombed town & 12.5 & $\mathrm{ND}^{*}$ & 8.03 & 414 & 2.41 & $\mathrm{ND}^{*}$ \\
\hline 13 & $29^{\circ} 41^{\prime} 45.1253^{\prime \prime} \mathrm{N}$ & $47^{\circ} 40^{\prime} 3.4908^{\prime \prime} \mathrm{E}$ & open area used for camping & ND* & ND* & 10.6 & 455 & 2.00 & 12.6 \\
\hline 14 & $29^{\circ} 39^{\prime} 52.7104^{\prime \prime} \mathrm{N}$ & $47^{\circ} 40^{\prime} 37.7851^{\prime \prime} \mathrm{E}$ & open area used for camping & 8.92 & 15.9 & 10.1 & 396 & 0.962 & 23.1 \\
\hline 15 & $29^{\circ} 35^{\prime} 0.1126^{\prime \prime} \mathrm{N}$ & $47^{\circ} 40^{\prime} 15.5406^{\prime \prime} \mathrm{E}$ & open area used for camping & 32.3 & 8.70 & 17.9 & 403 & 3.33 & 23.6 \\
\hline 16 & $29^{\circ} 24^{\prime} 42.3698^{\prime \prime} \mathrm{N}$ & $47^{\circ} 38^{\prime} 27.3834^{\prime \prime} \mathrm{E}$ & open area used for camping & 17.3 & $\mathrm{ND}^{*}$ & 8.29 & 355 & 1.15 & 15.0 \\
\hline
\end{tabular}

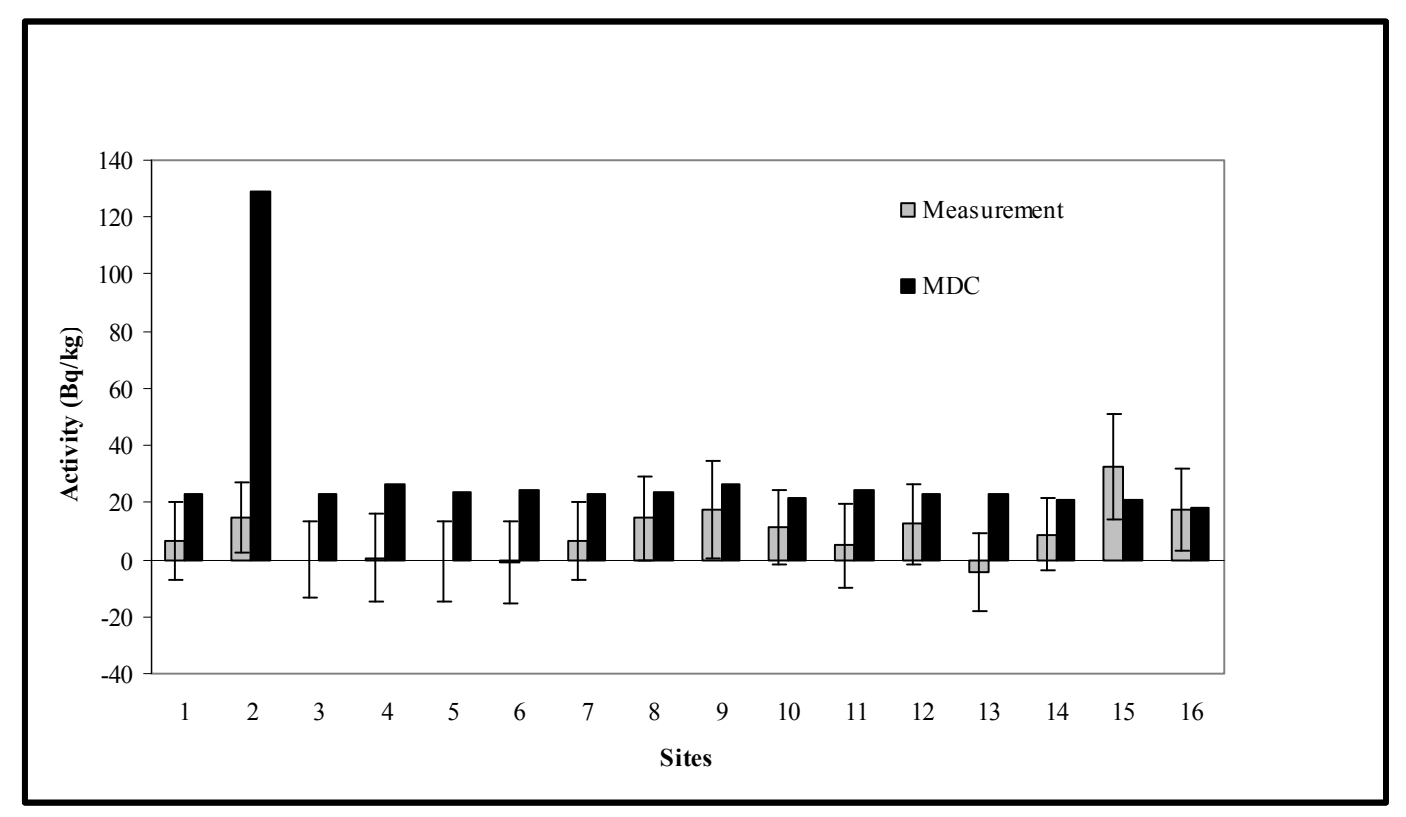

Figure 2. Activity concentration of Uranium-238 measured in the sand samples 


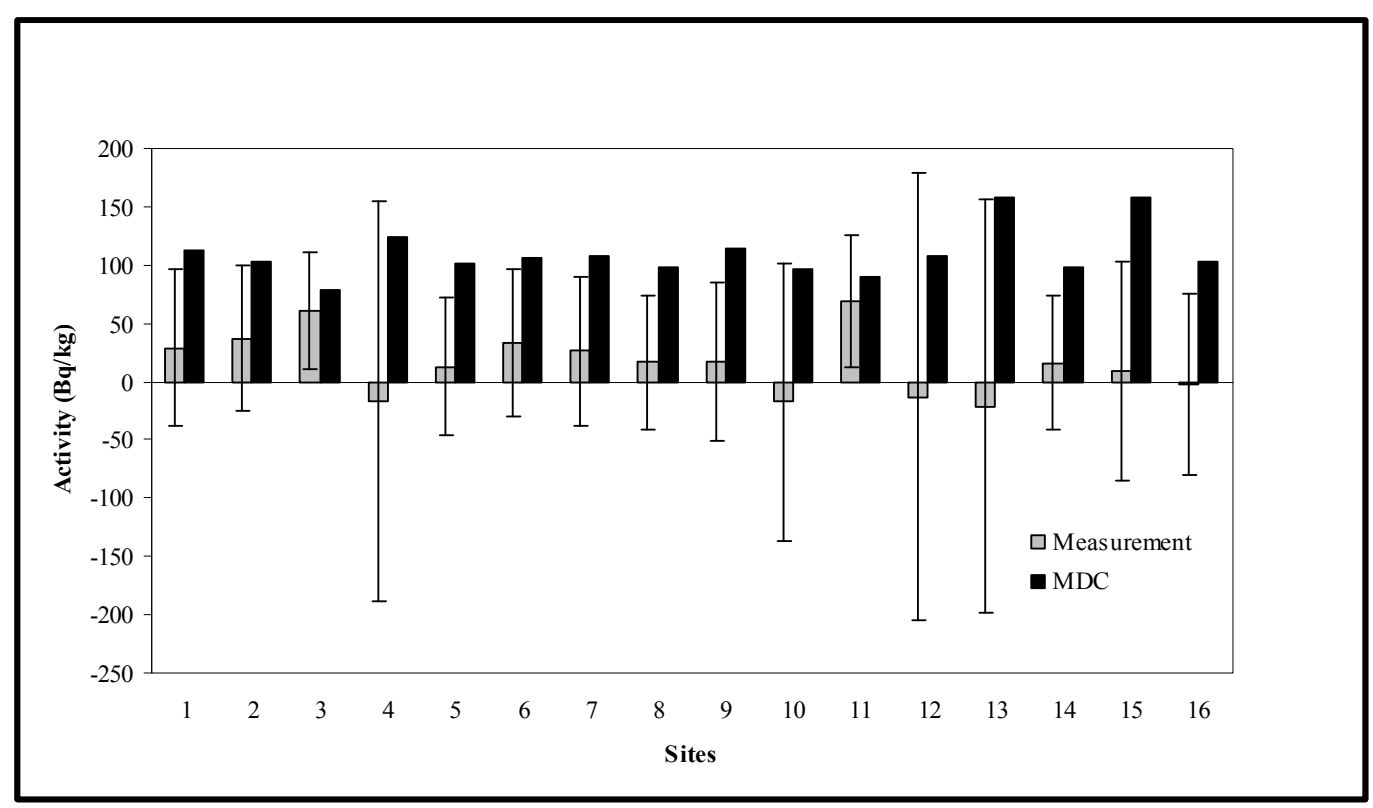

Figure 3. Activity concentration of Thorium-232 measured in the sand samples

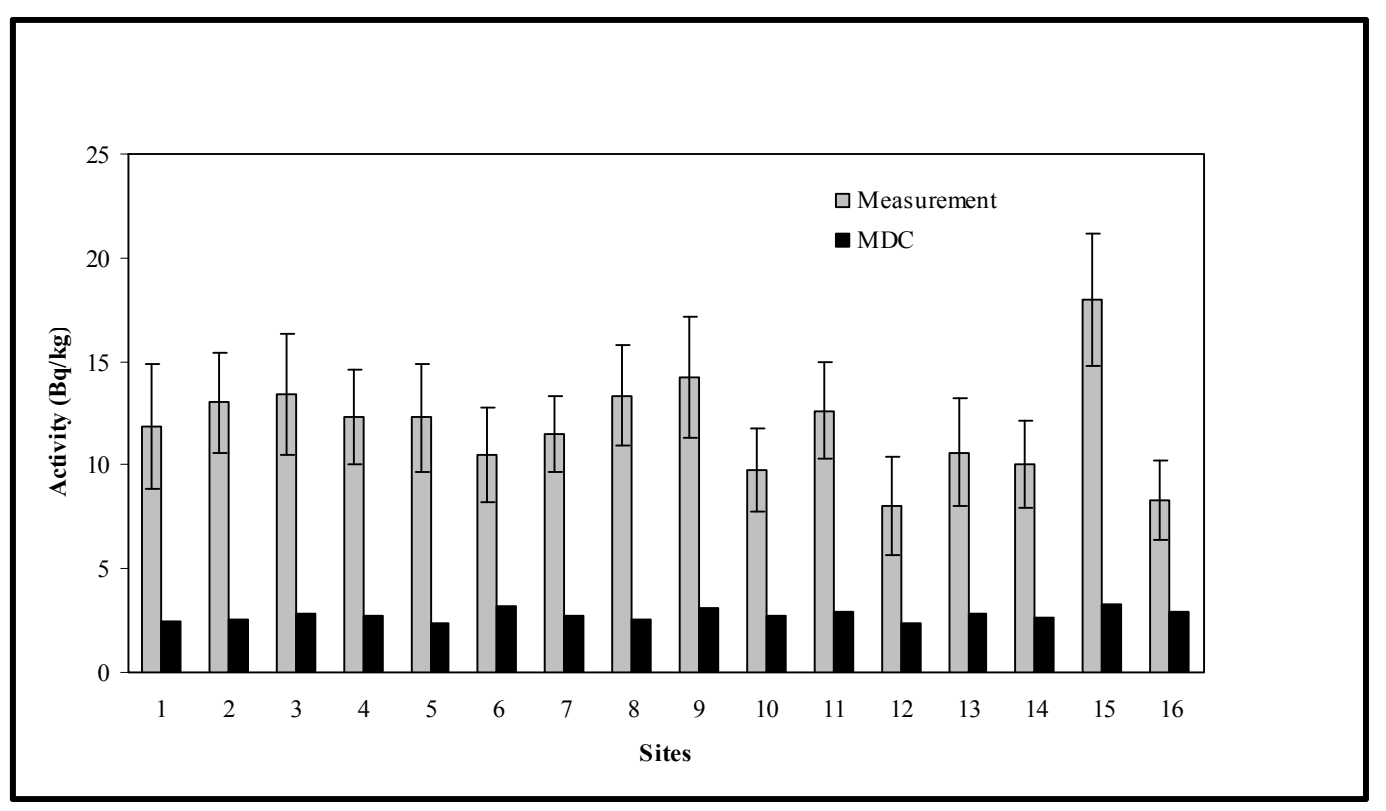

Figure 4. Activity concentration of Radium-226 measured in the sand samples 


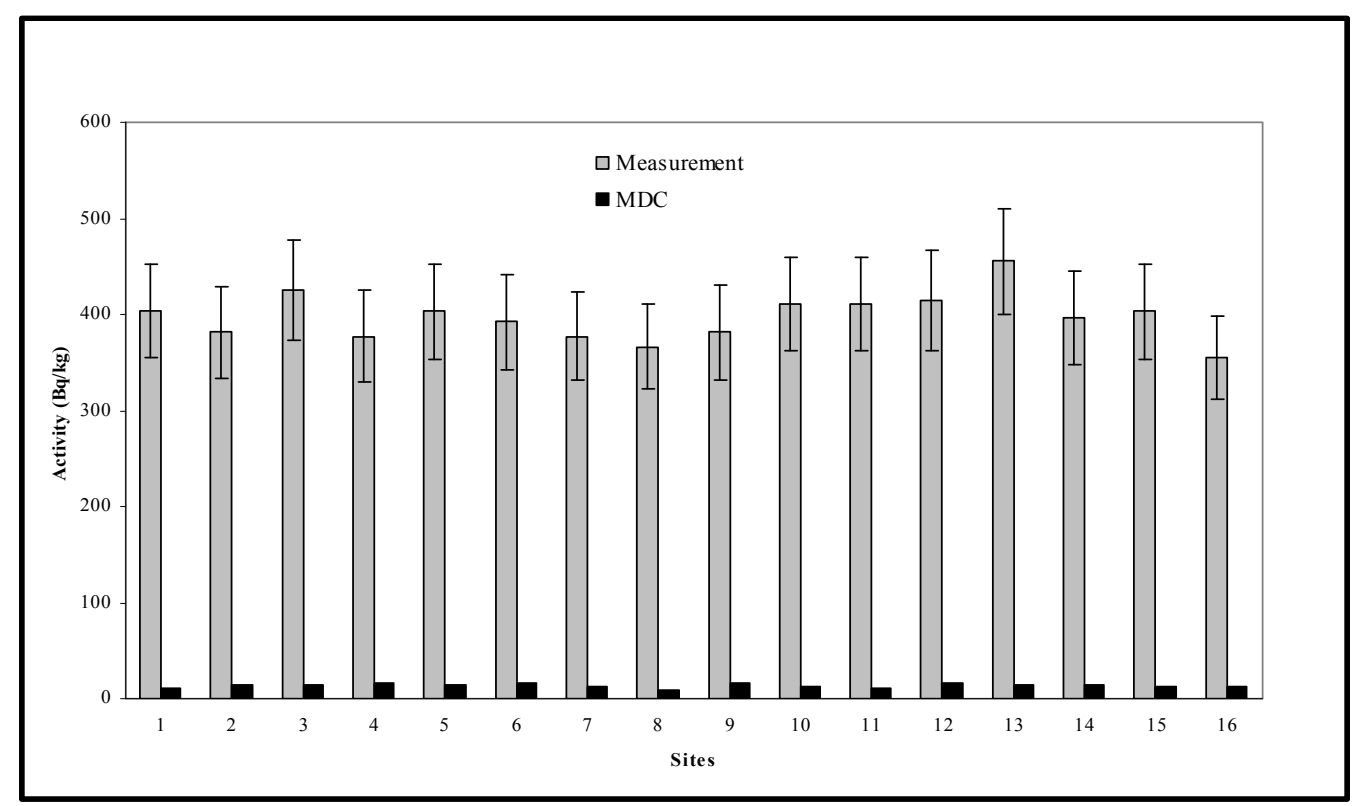

Figure 5. Activity concentration of Potassium- 40 measured in the sand samples

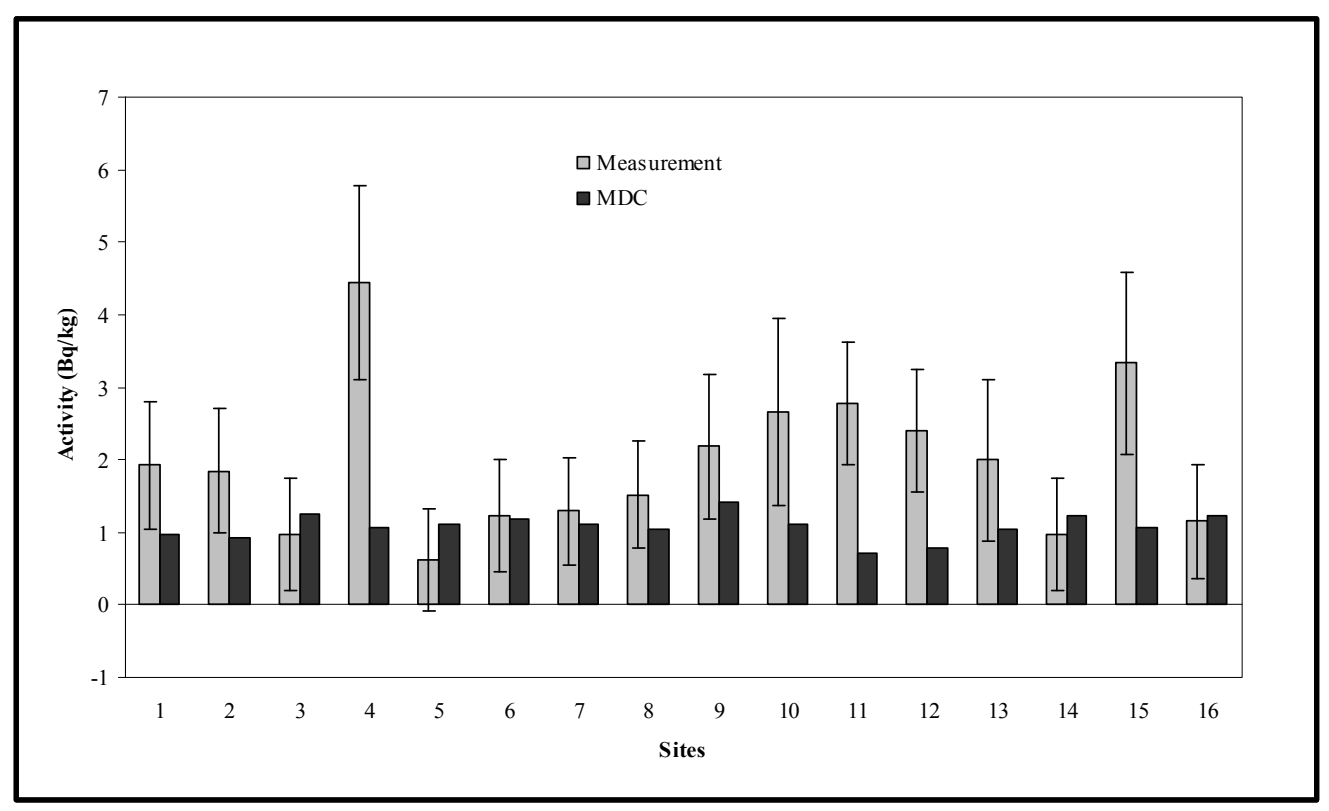

Figure 6. Activity concentration of Cesium-137 measured in the sand samples 


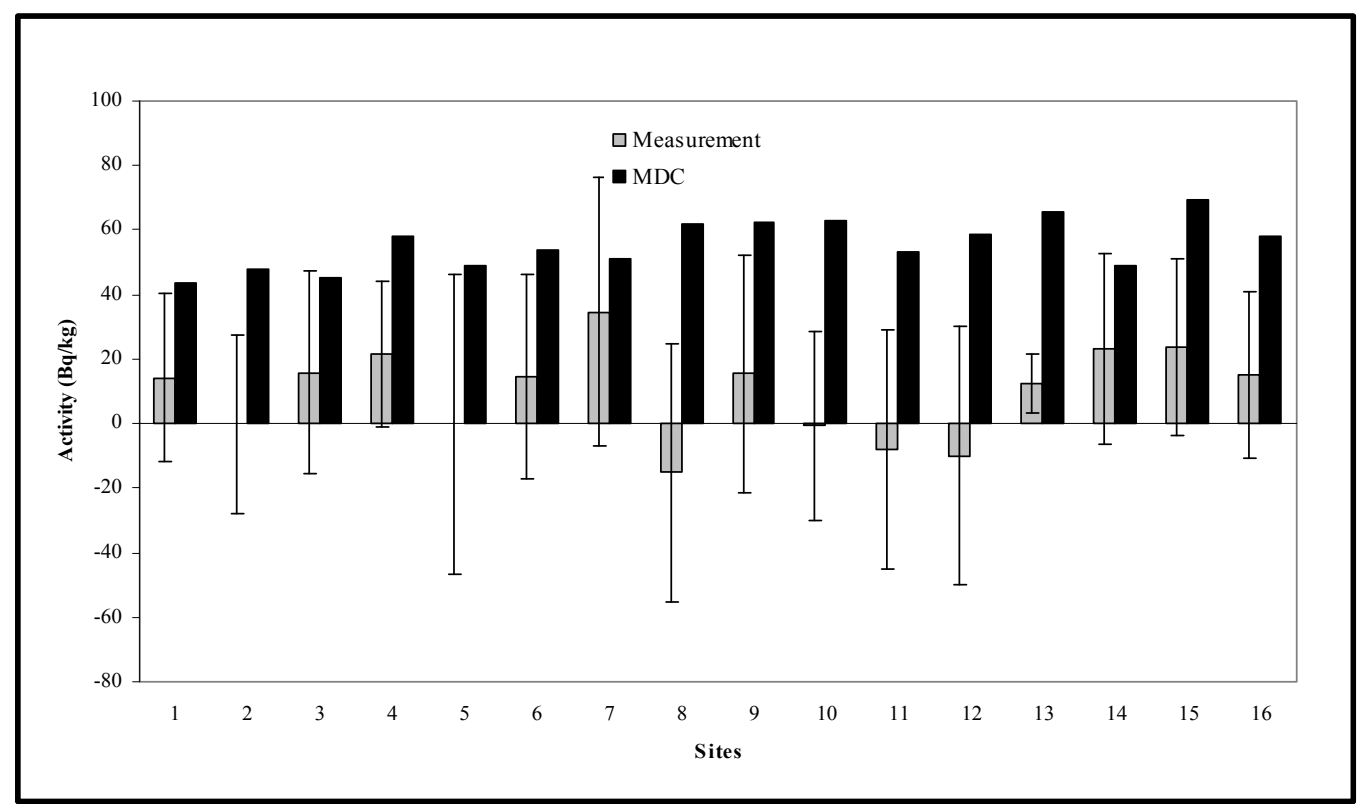

Figure 7. Activity concentration of Iodine-131 measured in the sand samples

(4.958-17.39 Bq/kg; Sites 9, 10, 11, and 12), followed by an agricultural area close to the border with Iraq (6.771 and $14.541 \mathrm{~Bq} / \mathrm{kg}$; Sites 7 and 8). The remaining sites (3, 4, 5, 6, and 13) had negligible concentrations of Uranium-238. The average concentration of Uranium-238 in the area under investigation reported in the radiological atlas of Kuwait ranged from 11.9-16.1 Bq/kg. In addition, the data presented in the literature spanned from 13 to $40 \mathrm{~Bq} / \mathrm{kg}$ (Al-Azmi, Saad, \& Farhan, 1999; Saad \& Al-Azmi, 2002; Bou-Rabee \& Bem, 1996; IAEA, 2003; KISR, 2008). Thus, the Uranium-238 concentrations reported in this study are within these values and the relatively high radioactivity concentrations of Uranium-238 reported at site 15 could be related to the deposition of volatile depleted uranium.

In nature, thorium is estimated to be about three to four times more abundant than uranium in the Earth's crust. Virtually all thorium is found as Thorium-232, which undergoes alpha decay with a half-life of about 14.05 billion years to produce a radio-active gas, Radon-220. In addition to, secondary decay products of thorium include radium and actinium. From Figure 3, it can be inferred that the Thorium-232 concentration ranged from 8.7 Bq/kg (Site 15) to $60.3 \mathrm{~Bq} / \mathrm{kg}$ (Site 3). This thorium concentration is higher than the ones reported in the literature (2.3-27.9 Bq/kg) (Abdullah, Saad, Farhan, \& Sharma, 2008; Saad \& Al-Azmi, 2002). Since thorium exists naturally, its high concentration could be related to the geological make-up of the rocks in Kuwait such as limestone, sandstone, and shale which tend to have high concentrations of three naturally occurring radio nuclides namely: Thorium-232, Radium-226, and Potassium-40 (Saad \& Al-Azmi, 2002).

In the natural environment, Radium-226 occurs at very low levels in virtually all rock, soil, and water; in addition, it is a decay product of uranium and thorium. Thus, when uranium and thorium occur in relatively high levels in rock or soil, radium is also found in high levels. As shown in Figure 4, the concentration of Radium -226 ranges from $8.03 \mathrm{~Bq} / \mathrm{kg}$ (Site 12) to $17.94 \mathrm{~Bq} / \mathrm{kg}$ (Site 15), where this determined concentration falls within the concentration found in the literature (11.5-59.8 Bq/kg) (Al-Azmi, Saad, \& Farhan, 1999; Saad \& Al-Azmi, 2002; Bou-Rabee \& Bem, 1996; KISR, 2008).

Potassium- 40 with a relative abundance of $0.01 \%$ is the radioactive isotope of potassium. Potassium- 40 , along with uranium and thorium, constitute the three most abundant naturally occurring elements in rocks and soil. From Figure 5, it can be deduced that the Potassium-40 concentrations ranged from $354.83 \mathrm{~Bq} / \mathrm{kg}$ (Site 16) to $455.1 \mathrm{~Bq} / \mathrm{kg}$ (Site 13). Previous studies indicated the Potassium- 40 concentration ranges from $110.3 \mathrm{~Bq} / \mathrm{kg}$ to 632.0 Bq $/ \mathrm{kg}$, thus making the Potassium-40 concentrations plotted in Figure 5 to fall within acceptable levels (Al-Azmi, Saad, \& Farhan, 1999; Saad \& Al-Azmi, 2002; Bou-Rabee \& Bem, 1996; KISR, 2008).

Nonradioactive cesium occurs naturally in various minerals, while radioactive cesium, Cesium-137, is produced when uranium and plutonium absorb neutrons and undergo fission. Cesium-137 in the environment came from a variety of sources where the largest single source is attributed to the fallout from atmospheric nuclear weapons 
testing in the 1950s and 1960s, which dispersed and deposited cesium-137 world-wide. In addition to, nuclear reactor waste and accidental releases such as the Chernobyl accident in the Ukraine released some Cesium-137 to the environment. Figure 6 illustrates the Cesium-137 concentration with the highest at $4.44 \mathrm{~Bq} / \mathrm{kg}$ (Site 4 ) and the lowest at $0.629 \mathrm{~Bq} / \mathrm{kg}$ (Site 5).

Iodine-131, called radioiodine, is an important radioisotope of iodine. Iodine-131 is produced by the fission of uranium atoms during operation of nuclear reactors and by plutonium (or uranium) in the detonation of nuclear weapons at an estimated $3 \%$ by weight of the total fission products; it has a radioactive decay half-life of about eight days. Iodine-131 was introduced in the environment through open-air atomic bomb testing back in the 1950s and 1960s, and from the Chernobyl disaster. Figure 7 summarizes the Iodine-131 data collected in this study where the concentration ranged from $12.58 \mathrm{~Bq} / \mathrm{kg}$ (Site 12) to $34.71 \mathrm{~Bq} / \mathrm{kg}$ (Site 7).

No radioiodine data for the state of Kuwait was found in the literature; on the other hand, the Cesium-137 reported concentrations spread from 1.31 to $4.45 \mathrm{~Bq} / \mathrm{kg}$ (Biegalski, Hosticka, \& Mason, 2001; Saad \& Al-Azmi, 2002; KISR, 2008) which render the current Cesium-137 concentrations acceptable. The Cesium-137 detected concentrations can be definitely linked to the Chernobyl accident back in 1986 where the estimated amount of Cesium-137 released was $9.0 \times 10^{16} \mathrm{~Bq}$. According to International Atomic Energy Agency, this tremendous amount of radioactive material was deposited over the entire northern hemisphere including the Middle East region. Since the present study took place 26 years after the accident, it is expected to detect Cesium-137 due to its half-life of 30.1 years.

Table 3 (Saad \& Al-Azmi, 2002) illustrates the mean activity concentrations of the terrestrial primordial nuclides found in soil of different countries. The list of countries includes both industrialized and developing countries. In addition, the world average data is also listed for comparison. It is clearly established that the radioactivity measurements conducted in this study are either below (Uranium-238 and Radium-226) or within (Thorium-232 and Potassium-40) the reported levels. The current legal limit for Iodine-131 is set at $2000 \mathrm{~Bq} / \mathrm{kg}$; furthermore, the one set for Cesium-137 is currently at $500 \mathrm{~Bq} / \mathrm{kg}$ and both limits are enforced by the European Union, Japan, and the United States of America. In this study, the mean activity concentration determined for Cesium-137 is $2.0 \mathrm{~Bq} / \mathrm{kg}$ and for Iodine-131 is $19.0 \mathrm{~Bq} / \mathrm{kg}$, where both are well below the current legal limits. In light of these findings, the investigated area in this research article is definitely not radiologically hazardous. 
Table 3. The mean activity concentrations of primordial radioisotopes in different countries

\begin{tabular}{ccccc}
\hline Country & \multicolumn{4}{c}{ Mean Activity $(\mathrm{Bq} / \mathrm{kg})$} \\
\cline { 2 - 5 } & ${ }^{238} \mathrm{U}$ & ${ }^{232} \mathrm{Th}$ & 12 & 397 \\
\hline Kuwait-Present Study & 11 & 30 & 50 & 524 \\
China (1988) & 62 & 90 & --- & 1711 \\
Turkey (1997) & 75 & 24 & 60 & 350 \\
Republic of Ireland & 37 & 26 & & \\
(1988) & & & 45 & 650 \\
Spain (1992) & 33 & 49 & --- & 495 \\
The Netherlands (1988) & --- & 68 & 737 \\
Japan (1988) & --- & 28 & 390 \\
Belgium (1988) & --- & 38 & 1240 & 2100 \\
Norway (1988) & --- & 323 & 1046 \\
Italy (1988) & --- & 212 & 1130 \\
Greece (1996) & 214 & 43 & 38 & 599 \\
France (1992) & 37 & 38 & 36 & 272 \\
Bangladesh (1999) & 38 & 66 & 43 & 385 \\
Bulgaria (1998) & 44 & 58 & --- & 47 \\
Portugal (1998) & & 73 & --- & 479 \\
Taiwan (1992) & 18 & 28 & --- & 316 \\
Egypt (1993) & 17 & 18 & --- & 408 \\
Algeria (1998) & --- & --- & & 370 \\
World & 25 & 25 & &
\end{tabular}

\section{Conclusion}

Measurements of six radioactive nuclides in sand samples were carried out in this study. The samples were collected from an area stretching north from Kuwait City to the border with Iraq. The results attained show undoubtedly that the mean activities of the investigated radio nuclides in the sand are low compared to average levels reported worldwide.

\section{References}

Abdullah, F. H., Saad, H. R., Farhan, A. R., \& Sharma M. M. (2008). Investigation of naturally occurring radioactive materials (NORM) in oil fields and oil lakes in Kuwait. Paper presented at the Society of Petroleum Engineers conference on health, safety, and environment in oil and gas exploration and production, Nice, France, 15-17 April (SPE111562).

Al-Azmi, D., Saad, H. R., \& Farhan A. R. (1999). Comparative study of desert truffles from Kuwait and other countries in the Middle East for radionuclide concentration. Biological Trace Element Research, 71-72, 309-315. http://dx.doi.org/10.1007/BF02784217

Barnaby, F. (1991). The environmental impact of the Gulf War. The Ecologist, 21(4), 166-172.

Biegalski, S. R., Hosticka, B., \& Mason, L. R. (2001). Cesium-137 concentrations, trends, and sources observed in Kuwait City, Kuwait. Journal of Radioanalytical and Nuclear Chemistry, 248(3), 643-649. http://dx.doi.org/10.1023/A:1010624224587

Bou-Rabee. F., \& Bem H. (1996). Determination of concentrations of selected radio nuclides in surface soil in the state of Kuwait. A paper presented at the International Radiation Protection Association conference, Vienna, Austria, 14-19 April (pp. 207-209).

International Atomic Energy Agency. (2003). Radiological conditions in areas of Kuwait with residues of depleted uranium. Austria: IAEA. 
Kuwait Institute for Scientific Research. (2008). Radiological atlas for the state of Kuwait. Kuwait: KISR.

Saad, H. R., \& Al-Azmi, D. (2002). Radioactivity concentrations in sediments and their correlation to the coastal structure in Kuwait. Applied Radiation and Isotopes, 56, 991-997. http://dx.doi.org/10.1016/S0969-8043(02)00061-1

\section{Copyrights}

Copyright for this article is retained by the author(s), with first publication rights granted to the journal.

This is an open-access article distributed under the terms and conditions of the Creative Commons Attribution license (http://creativecommons.org/licenses/by/3.0/). 